\title{
QUALITY OF SWEET POTATO AS A RAW MATERIAL FOR FOOD PROCESSING
}

Barbara SAWICKA, Department of Plant Cultivation Technology and Commodities Sciences, University of Life Sciences, Faculty of Agrobioengineering, Akademicka 15, 20-950 Lublin, Poland, barbara.sawicka@ up.lublin.pl(corresponding author)

Barbara KROCHMAL-MARCZAK, Department of Food Safety, State Higher Vocational School. St. Pigonia in Krosno, Dmochowskiego 12, Poland, bkmarczak@gmail.com

Dominika SKIBA, Department of Plant Cultivation Technology and Commodities Sciences, University of Life Sciences, Faculty of Agrobioengineering, Akademicka 15, 20-950 Lublin, dominikaskiba81@gmail.com

Piotr PSZCZÓŁKOWSKI, Experimental Station of Varieties Ratings in Uhnin, COBORU, Uhnin, 21-211 Dębowa Kłoda, Poland; P.Pszczolkowski.inspektor@coboru.pl

The aim of the study was to assess the possible antioxidant and antiproliferative effects of various sweet potato extracts (Ipomoea batatas [L.] Lam) in terms of their suitability for food processing. Antioxidant activity of water infusions from the leaves of 5 sweet potato varieties (Carmen Rubin, Cananua, Georgia Jet, Satsumo Imo, White Triumph) obtained from field cultivation in Felin $\left(51^{\circ} 13{ }^{\prime} \mathrm{N}, 2^{\circ} 37^{\prime} \mathrm{E}\right) \mathrm{was}$ determined. The field experiment was carried out using the randomized blocks method, in triplicate, in accordance with the principles of good agricultural practice. The leaves were collected at phase 68 according to the $\mathrm{BBCH}$ scale. After harvesting, the leaves were dried to constant weight. After drying, the leaves were saturated with water at $80^{\circ} \mathrm{C}$ and $100{ }^{\circ} \mathrm{C}$ for 3,6 and 9 minutes. The total content of phenolic compounds was determined by the method of Ghasemzadeh et al. Antioxidant activity of sweet potato leaf infusions was determined by DPPH radical spectrophotometry. The time to prepare the infusions significantly differentiated the TP content. Infusions evaluated after 3 minutes were the most favorable in this respect. The antioxidant activity of the tested infusions obtained from sweet potato leaves ranged from $33 \%$ to $59 \%$, depending on the variety, and $34-43 \%$, depending on the time the infusion was prepared. Leaf infusions prepared at $100^{\circ} \mathrm{C}$ had a higher antioxidant activity than infusions made at $80^{\circ} \mathrm{C}$. The highest antioxidant activity was revealed by infusions from White Triumph cultivar leaves, lowest - from Cananua cultivar leaves.

Keywords: innovations, cultivars, oxidant activity, sweet potato

\section{Acronyms:}

ABTS - 2,2'-azino-bis(3-ethylbenzothiazoline-6-sulfonate) diammonium salt;

CV - cultivars;

DNA - deoxyrybonucleic acid);

DPMD - DPPH - (2,2’-diphenylo-1-picrylhydrazyl); DPPP - difenylo-1-pyrenylofosfina (diphenyl-1-pyrenylphosphine);

mtDNA -mitochondrial DNA);

RFT - (ROS - reactive oxygen species);

TP - total phenolic

TRAP - total redox antioxidant parameter);

UV - (ultra-violet).

\section{INTRODUCTION}

In recent times, the interest of consumers, as well as the food and pharmaceutical industry, in nutrients of vegetable origin with antioxidant properties, has increased. These substances play an important role in the fight against free radicals that react with protein molecules, lipids and saccharides causing their oxidation, and as a consequence, destroy cellular and tissue structures and contribute to the development of many diseases. Low-molecular-weight substances with high antioxidant and antiradical activity are vitamins $\mathrm{E}$ and $\mathrm{C}$, carotenoids and polyphenol compounds of plant origin. Therefore, the foods with high antioxidant potential can significantly reduce the risk of cardiovascular disease and some cancers (Karadag et al., 2009; Hue et al., 2012; Koss-Mikołajczyk et al., 2017). Reactive oxygen species (ROS) are chemically active molecules that arise primarily through enzymatic or non-enzymatic cellular metabolism reactions. Enzymatic reactions include: respiratory chain reactions, phagocytosis, prostaglandin synthesis and the cytochrome P-450 system. ROS can also be activated as a result of non-enzymatic oxygen reactions with organic compounds and in response to adverse environmental factors, such as ionizing

Copyright () 2019 The Authors. Published by Vytautas Magnus University. This is an open-access article distributed under the terms of the Creative Commons Attribution License (CC BY 4.0), which permits unrestricted use, distribution, and reproduction in any medium, provided the original author and source are credited. 
or ultraviolet radiation, or toxic chemical compounds (Lobo et al. 2010). The role of ROS and reactive nitrogen (RFA) is important in so-called stress oxidative as well as in cellular signaling pathways. ROS not only have a harmful effect on the human body. Currently, attention is paid to the so-called "second face" of ROS, i.e. their physiological functions, such as: participation in extracellular and intracellular signaling pathways involved in cell proliferation, differentiation and apoptosis (Ray et al., 2012; Ye et al., 2015; Zuo et al., 2015). It is now believed that ROS do not threaten the proper functioning of cells as long as it is maintained in them. redox homeostasis, i.e. a balance between the amount of ROS and the concentration of antioxidant substances. Under physiological conditions, the level of ROS is controlled by the body's antioxidant defense system. It is only the excess of ROS that has not been neutralized in the cells that can cause oxidative stress, which may result in oxidative damage to many molecules, including lipids, proteins and nucleic acids (Towne et al., 2004; Rahman et al. 2012, Sies, 2012; Schieber et al., 2014). It is now recognized that these threats are not only prevented the body's antioxidant defense system, but also antioxidant substances, consumed with foods, especially of plant origin. Antioxidants can be defined as reducing and / or anti-radical substances that counteract damage caused in cells RFT activity. This definition applies to low molecular weight chemical compounds with high reduction potential. However, also macromolecules can counteract the harmful effects of oxidation, such as enzymes or certain cellular structures. They are also known as antioxidants. The term is taken from English and refers to all molecules capable of capturing and / or reducing pro-oxidants. There are currently 5 mechanisms of antioxidant activity (Hue et al., 2012):

- antioxidants forming a physical barrier preventing the formation of ROS and their penetration into important biological structures, e.g. redox active substances in the cell membrane or UV filters,

- chemical TRAPs absorbing energy or binding electrons derived from ROS, i.e. compounds most closely related to the definition of antioxidants, which include e.g. carotenoids and anthocyanins,

- catalytic systems responsible for neutralizing ROS, e.g. antioxidative enzymes such as superoxide dismutase, glutathione peroxidase, catalase (Končić et al. 2012),

- antioxidants capable of chelating metal ions and thereby preventing the formation of ROS, e.g. catechins,

- antioxidants interrupting the oxidation reaction chain by catching RFT, e.g. ascorbic acid or tocopherols (Karadag et al., 2009; Hue et al., 2012; Ghasemzadeh et al., 2012; Koss-Mikołajczyk et al., 2017).

The increase in interest of both scientists and public opinion reactive in recent years' oxygen forms (ROS) is caused by the dual nature of these substances. On the one hand, ROS perform mediators and metabolism regulators in homeostasis. On the other hand, however, their excessive production and exhaustion of natural antioxidant reserves by the body induces stress oxidative, which is the basis of most civilization diseases, such as atherosclerosis, hypertension and cancer. However, along with the understanding of the mechanisms responsible for the formation of oxidative stress, remedies against them were sought, that is:

- reducing and / or anti-radical substances that could counteract damage to cells caused by ROS. Particular attention is paid to antioxidants provided with food that support the body's natural antioxidant defense against damage caused by disturbed redox homeostasis, so they can counteract and / or slow down development and support the treatment of these diseases. This stimulates the search for better methods of determination antioxidant activity under culture conditions phones that can better reflect in vivo antioxidant activity (Ishiguro \& Yoshimoto 2006).

- The use of classic chemical methods used in this study does not provide information on the actual effect of antioxidants in the human body. Bioavailability, distribution and metabolism of antioxidant substances in vivo they can show while tests carried out under cell culture conditions (Končić et al., 2012; Różańska et al., 2014; Koss-Mikołajczyk et al., 2017).

- The most commonly used methods of determination RFT levels and the ability of antioxidants to do so neutralization in biological systems rely mainly on the measurement of chemiluminescence or fluorescence of products resulting from the reaction of RFT with probes, which acquire the ability to emit radiation due to oxidation (Kurata et al. 2007; Sawicka et al., 2018).

- The cultivar of available probes and control RFT sources allows you to choose the optimal system that is best suited to assess the antioxidant activity of the test substances, in this case sweet potato leaf extracts (Ishiguro and Yoshimoto, 2006; Olowu et al., 2011; Koss-Mikołajczyk et al. 2017).

Sun and others (2018) have shown that in the Chinese purple sweet potato variety there are as many as 12 types of anthocyanins from (Ipomoea batatas (L.) Lam.) based on peonidine. Ingredients based on peonidine in purple sweet potato anthocyanins (PSPA) show good scavenging properties of 1,1-diphenyl-2-picrylhydrazyl radicals (DPPH) and superoxide anions, and have good potential in reducing overall activity and in $\mathrm{Fe} 2+$ chelating capacity. Kubow et al. (2016) found that microbial cultures have shown that peonidin 3-p-hydroxy-benzoyl-sophoroside-5-glucoside; peonidin 3-(600-p-coumaroylsophoroside)-5-glucoside; peonidin-3-p-coumaroyl-rutinoside-5-glucosid; peonidin 3-caffeoyl-p-hydroxybenzoylsophoroside-5-glucoside and peonidin 3-feruloyl-p-caffeoyl-sophoroside-5-glucoside and PSPA peonidines can induce the proliferation of Bifidobacterium bifidum, Bifidobacterium adolescentis, Bifidobacterium infantis and Lactobacillus acidophilus, as well as inhibit the growth of Staphylococcus aureus and Salmonella. They can also cause the proliferation of Bifidobacterium bifidum, Bifidobacterium adolescentis, Bifidobacterium infantis and Lactobacillus acidophilus. Similar activity is through modulation of the intestinal microflora. According to Sun et al. (2018) peonidine-based anthocyanins can be further used in healthy food and pharmaceutical products. The species with high antioxidant potential is Ipomoea batatas 
L. [Lam.] - is sweet potato, who belongs to plants with high adaptation abilities and is now cultivated in Poland on commercial. Its tubers and leaves are a very good source of many vitamins such as: A, C, B (riboflavin) and lutein. Infusions made of sweet potato leaves are used, among others, in the treatment of type 2 diabetes (Končić et al., 2012; KrochmalMarczak and Betlej, 2014; Krochmal-Marczak et al., 2019; Sawicka et al., 2000, 2004, 2018). Therefore, the purpose of the research was to assess the possible antioxidant and antiproliferative effects of various sweet potato extracts (Ipomoea batatas [L.] Lam) in terms of their suitability for food processing.

\section{MATERIAL AND METHODS}

The basis for the study was plant material from a field experiment conducted in 2018 , in Felin $\left(51^{\circ} 13^{\prime} \mathrm{N}, 22^{\circ} 37^{\prime} \mathrm{E}\right)$, on Cambisols, slightly acid soil. They were established in a completely randomized block carried out, in 3 replications. The factor of the experiment was 5 cultivars of sweet potato (Cananua, Carmen Rubin, Georgia Jet, Satsumo Imo, White Triumph). Fertilization was carried out at a constant level, and care treatments in accordance with good agricultural practice. The leaves were collected in phase 68 according to the $\mathrm{BBCH}$ scale. The collected leaves were thoroughly washed with water to remove dirt. After drying in the shade, the leaves were dried with a lyophilizer (SGS Lab Instruments, Chennai, India) and then ground to a fine powder and stored at $-80^{\circ} \mathrm{C}$ for future analysis (Ghasemzadeh et al., 2010).

Preparation of the extract. Sweet potato leaves were freeze dried to constant weight before use for extraction. One gram of powder was extracted continuously with methanol $(80 \%, 50 \mathrm{ml})$. The solution was then centrifuged for 1 hour at room temperature using an orbital shaker (SuperLab, Uttam Nagar, Delhi, India) The extracts were then filtered under reduced pressure and stored at $-20^{\circ} \mathrm{C}$ until further use. Samples of $2 \mathrm{~g}$ dried leaves were weighed and placed in $250 \mathrm{ml}$ flasks, then filled to $100 \mathrm{ml}$ with boiled drinking water at $80^{\circ} \mathrm{C}$ and $100^{\circ} \mathrm{C}$. Three brewing time were used: 3,6 and 9 minutes. After brewing, the infusions were filtered, and the extracts obtained were cooled to a temperature of about $25^{\circ} \mathrm{C}$. Fife replicates were prepared for each combination.

Determination of total phenols. The total phenol content determined by the method of Ghasemzadeh et al. (2010). $1 \mathrm{ml}$ of the extract was added to deionized water $(10 \mathrm{ml})$ and Folin-Ciocalteu phenolic reagents $(1.0 \mathrm{ml})$. After 5 minutes, $20 \%$ sodium carbonate $(2.0 \mathrm{~mL})$ was added to the mixture. The solution was kept in total darkness, and absorbance was measured at $750 \mathrm{~nm}$ using a spectrophotometer (U-2001, Hitachi Instruments Inc., Tokyo, Japan). Gallic acid used as the standard and the total phenol content was expressed in $\mathrm{mg}$ of gallic acid. The TP content was tested after brewing the extract with water at $100^{\circ} \mathrm{C}$.

DPPH determination. The vial was successively filled with $2.9 \mathrm{ml} 96 \%$ ethanol, $1 \mathrm{ml} 0.3 \mathrm{M}$ ethanol solution DPPH and $0.1 \mathrm{ml}$ infusions. After mixing, the solution was incubated for 30 minutes in a dark place. At this time, a so-called A0 solution was prepared by mixing $3 \mathrm{ml}$ of $96 \%$ ethanol with $1 \mathrm{ml}$ of $0.3 \mathrm{M}$ DPPH solution. Before measuring the samples tested, the spectrophotometer was calibrated by measuring the absorption at wavelength $\lambda=517 \mathrm{~nm}$ with a $96 \%$ ethanol standard solution, and then compared against the A0 test solution. Before measurement, the vial contents were mixed thoroughly, poured into the cuvettes and absorbance spectra were immediately measured. All tests were performed in triplicate using a Jenway 6850 UV / VIS spectrophotometer (Ghasemzadeh et al., 2012; Koss-Mikołajczyk et al., 2017).

Antioxidant activity of infusions was expressed as a percentage reduction of the DPPH radical after 30 minutes of infusion incubation with reference to the control sample. For this purpose, the arithmetic mean was determined from the measurements obtained from the spectrophotometric analysis and then the values were assigned to the formula:

$$
\mathrm{A}[\%]=\frac{(A C-A S)}{A C * 100}, \text { where: }
$$

A - percent inhibition of free radicals; AC - absorbance of the control; AS - average absorbance value of the test infusion solution (Zych and Krzepiłko 2010, Ghasemzadeh et al. 2012).

A descriptive analysis of the test results was carried out using the Statistica 10 software (means, standard deviation). Significance of differences between means were calculated by Tukey's test at significance level p 0.05 . Test results were also subjected to analysis of variance using the SAS 9.2 statistical package (PROC GLM Tukey-test, SAS Institute Inc., Cary, NC, USA) and a P value $\leq 0.05$ was considered statistically significant (Stanisz 2007).

\section{RESULTS AND DISCUSSION}

Currently, phytochemicals and antioxidants in plants are generating consumer interest in the role of maintaining human health. Phenols and flavonoids are known for their health promoting properties due to their protective effect against cardiovascular diseases, cancer and other diseases (Tables 1-3).

The overall content of phenolic compounds was influenced by both the genetic characteristics of the plants from which the raw material was obtained, as well as the time to prepare the infusions. The infusion preparation time clearly differentiated the TP content of the infusions obtained. The most favorable in this respect was the infusion brewed for 3 
minutes, for each of the tested cultivars. As the leaf brewing time was prolonged, the overall content of polyphenols compounds (TP) gradually decreased (Table 1). The highest, significant content of total polyphenols had White Triumph (from $7.80 \pm 2.19 \mathrm{mg}$ to $5.78 \pm 1.02 \mathrm{mg}$ gallic acid $\mathrm{g}^{-1} \mathrm{DW}$ ), while the lowest Satsumo Imo (from $4.89 \pm 1.37 \mathrm{mg}$ to $3.32 \pm$ $1.36 \mathrm{mg}$ gallic acid. $\mathrm{g}^{-1} \mathrm{DW}$ ). In the research of Ghasemzadeh et al. (2012) TP content in sweet potato leaves ranged from 4.47 \pm 1.88 to $8.11 \pm 2.11 \mathrm{mg} \cdot \mathrm{g}^{-1} \mathrm{DW}$ in leaf extracts, and the highest TP content was observed in the Vardaman cultivar. Antioxidant activity determined by 1,1-diphenyl-2-picryl hydrazil (DPPH) and iron-reducing antioxidant (FRAP) showed in studies by Ghasemzadeh et al. (2012), high activities (IC50 value $184.3 \mu \mathrm{g} \mathrm{ml}^{-1}$ ) in the leaves of the Vardaman cultivar, while the Centennial cultivar showed the lowest activity (IC50 $=450.46 \mu \mathrm{g} / \mathrm{ml}$ ). According to Ghasemzadeh et al. (2012), antioxidant activity is strongly correlated with TP content $\left(\mathrm{R}^{2}=0.827\right)$, while no significant correlation was found between TF content and antioxidant activity $\left(\mathrm{R}^{2}=0.045\right)$. Hence, it can be concluded that the total phenol content can be a useful indicator of sweet potato antioxidant activity. This study also confirms the healing potential of sweet potato leaves.

Table 1. Total phenolic contents of the leaf extracts of Ipomoea batatas cultivars TP (mg gallic acid $\left.\mathrm{g}^{-1} \mathrm{DW}\right)$ brewed in water at $100^{\circ} \mathrm{C}$

\begin{tabular}{|l|c|c|c|}
\hline \multirow{2}{*}{ Cultivars } & \multicolumn{3}{|c|}{ Time brewing (min) } \\
\cline { 2 - 4 } & 3 & 6 & 9 \\
\hline Cananua & ${ }^{\mathrm{b}} 6.99 \pm 1.64^{\mathrm{x}}$ & ${ }^{\mathrm{b}} 4.90 \pm 0.98^{\mathrm{y}}$ & ${ }^{\mathrm{b}} 3.99 \pm 1,34^{\mathrm{z}}$ \\
Carmen Rubin & ${ }^{\mathrm{b}} 6.68 \pm 1.25^{\mathrm{x}}$ & ${ }^{\mathrm{c}} 5,27 \pm 1.11^{\mathrm{y}}$ & ${ }^{\mathrm{y}} 4.67 \pm 1.45^{\mathrm{z}}$ \\
Georgia Jet & ${ }^{\mathrm{b}} 6.22 \pm 1.09^{\mathrm{x}}$ & ${ }^{\mathrm{c}} 5.73 \pm 0,89^{\mathrm{y}}$ & ${ }^{\mathrm{a}} 3.72 \pm 0.67^{\mathrm{z}}$ \\
Satsumo Imo & ${ }^{\mathrm{a}} 4.89 \pm 1.37^{\mathrm{x}}$ & ${ }^{\mathrm{a}} 3.55 \pm 1.53^{\mathrm{y}}$ & ${ }^{\mathrm{a}} 3.32 \pm 1.36^{\mathrm{z}}$ \\
White Triumph & $\mathrm{c}^{\mathrm{c}} 7.80 \pm 2.19^{\mathrm{x}}$ & ${ }^{\mathrm{d}} 6.56 \pm 1.18^{\mathrm{y}}$ & ${ }^{\mathrm{d}} 5.78 \pm 1.02^{\mathrm{z}}$ \\
\hline Mean & $6.52^{\mathrm{A}}$ & $5.20^{\mathrm{B}}$ & $4.30^{\mathrm{C}}$ \\
\hline
\end{tabular}

$\mathrm{x}, \mathrm{y}, \mathrm{z}, \mathrm{A}, \mathrm{B}, \mathrm{C}$ values in the rows marked with different letters differ significantly (p>0.05)

$a, b, c$ values in the columns marked with different letters differ significantly $(p>0.05)$

The antioxidant activity of sweet potato leaves water infusions, determined using the DPPH radical, ranged from $34.72 \%$ to $58.96 \%$. Its value was influenced both by the genetic characteristics of the plants, from which the raw material was obtained, as well as the temperature and time of brewing preparation (Tables 2).

Table 2. Antioxidant activity of infusions from sweet potato leaves brewed in water at $100^{\circ} \mathrm{C}$

\begin{tabular}{|c|c|c|c|}
\hline \multirow{2}{*}{ Cultivars } & \multicolumn{3}{|c|}{ Time brewing (min) } \\
\hline & 3 & 6 & 9 \\
\hline Cananua & $\mathrm{a} 35.16 \pm 0.44^{\mathrm{x}}$ & ${ }^{\mathrm{a}} 52.20 \pm 0.88^{\mathrm{y}}$ & ${ }^{\mathrm{c}} 48.44 \pm 0.40^{\mathrm{z}}$ \\
\hline Carmen Rubin & $38.09 \pm 0.25^{x}$ & ${ }^{\mathrm{a}} 52.04 \pm 0.11^{\mathrm{y}}$ & $\mathrm{a} 46.21 \pm 0.45^{\mathrm{z}}$ \\
\hline Georgia Jet & ${ }^{b} 44.22 \pm 0.89^{x}$ & ${ }^{\mathrm{b}} 57.43 \pm 0,69^{y}$ & ${ }^{\mathrm{b}} 51.72 \pm 0.47^{\mathrm{z}}$ \\
\hline Satsumo Imo & ${ }^{c} 41.55 \pm 0.37^{x}$ & b $57.55 \pm 0,53^{y}$ & ${ }^{\mathrm{d}} 53.32 \pm 0.86^{\mathrm{z}}$ \\
\hline White Triumph & ${ }^{b} 44.70 \pm 0.49^{x}$ & ${ }^{\mathrm{b}} 58.16 \pm 0,8^{\mathrm{y}}$ & ${ }^{\mathrm{d}} 53.26 \pm 1.02^{\mathrm{z}}$ \\
\hline Mean & $40.74^{\mathrm{C}}$ & $55.48^{\mathrm{A}}$ & $50.59^{\mathrm{B}}$ \\
\hline
\end{tabular}

$\mathrm{x}, \mathrm{y}, \mathrm{z}, \mathrm{A}, \mathrm{B}, \mathrm{C}$ values in the rows marked with different letters differ significantly (p>0.05)

$\mathrm{a}, \mathrm{b}, \mathrm{c}$ values in the columns marked with different letters differ significantly $(\mathrm{p}>0.05)$

Antioxidant activity of sweet potato leaves determined at $80^{\circ} \mathrm{C}$ turned out to be different depending on the cultivar and time of brewing the leaves. The leaves of the White Triumph cultivar showed the highest antioxidant activity, while the lowest - Carmen Rubin, regardless of the brewing time. On average, the most favorable brewing time was 6 minutes, compared to brewing for 3 minutes. The extension of the brewing time did not bring the expected results, as the antioxidant activity was significantly reduced, compared to the brewing lasting 6 minutes (Table 3). Extending the brewing time to 9 minutes resulted in the infusion characterized by slightly lower antioxidant activity, both at $100^{\circ} \mathrm{C}(46.3-53.3 \%)$ and $80{ }^{\circ} \mathrm{C}(39.1-47.0 \%)$. The lowest value of this feature was recorded for infusions obtained after 3 minutes of brewing (respectively 35.2-44.7\% and 29.07-35.67\%) (Table 2, 3).

Table 3. Antioxidant activity of infusions from sweet potato leaves brewing in water at $80^{\circ} \mathrm{C}$

\begin{tabular}{|c|c|c|c|}
\hline \multirow[t]{2}{*}{ Cultivars } & \multicolumn{3}{|c|}{ Time brewing (min) } \\
\hline & 3 & 6 & 9 \\
\hline Cananua & ${ }^{c} 29.06 \pm 0.54^{x}$ & ${ }^{\mathrm{c}} 44.80 \pm 0.68^{\mathrm{y}}$ & ${ }^{c} 45.14 \pm 0.80^{z}$ \\
\hline Carmen Rubin & a $34.39 \pm 0.15^{\mathrm{x}}$ & ${ }^{\mathrm{a}} 41.01 \pm 0.91^{\mathrm{y}}$ & a $39.01 \pm 0.45^{\mathrm{z}}$ \\
\hline Georgia Jet & b $32.82 \pm 0.69^{x}$ & b $44.13 \pm 0,99^{y}$ & $\mathrm{~b} 42.62 \pm 0.66^{\mathrm{z}}$ \\
\hline Satsumo Imo & b $32.55 \pm 1.37 x$ & ${ }^{\mathrm{cd}} 47.45 \pm 0,42^{\mathrm{y}}$ & $\mathrm{c} 45.75 \pm 0.76^{\mathrm{z}}$ \\
\hline White Triumph & $35.67 \pm 0.49^{x}$ & ${ }^{\mathrm{d}} 48.36 \pm 0,18^{\mathrm{y}}$ & ${ }^{\mathrm{d}} 47.03 \pm 0.82^{\mathrm{z}}$ \\
\hline Mean & $32.90^{\mathrm{C}}$ & $45.15^{\mathrm{A}}$ & $43.91^{\mathrm{B}}$ \\
\hline
\end{tabular}

$\mathrm{x}, \mathrm{y}, \mathrm{z}, \mathrm{A}, \mathrm{B}, \mathrm{C}$ values in the rows marked with different letters differ significantly $(\mathrm{p}>0.05)$

$a, b, c$ values in the columns marked with different letters differ significantly $(p>0.05)$ 
The infusion preparation time clearly differentiated the antioxidant activity of the infusions obtained. The most favorable in this respect was the infusion brewed for 6 minutes, for each of the tested cultivars, both using water at $80^{\circ} \mathrm{C}$ and $100^{\circ} \mathrm{C}$. Achieved values of this feature were in the range of $52.04-58.16 \%$ at $100^{\circ} \mathrm{C}$ and $41.01-48.36 \%$ at $80^{\circ} \mathrm{C}$. Similar results were reported by Yen and Chem (1995), who found the most antioxidant compounds in 5-minute infusions. Dmowski et al. (2014) gived that prolonging the brewing time from 3 to 15 minutes resulted in an increase in antioxidant activity, but only for some types of black teas. Wang et al. (2005) found that excessively long brewing time significantly reduces the antioxidant properties. This is also confirmed by the conducted research.

The temperature of the water used to prepare the infusions significantly influenced the antioxidant potential of the infusions obtained. After pouring the leaves with water at $100^{\circ} \mathrm{C}$, infusions with significantly higher antioxidant activity were obtained compared to infusions obtained with water at $80^{\circ} \mathrm{C}$. When pouring water at $100^{\circ} \mathrm{C}$, infusions of Cananua, Carmen Rubin and Georgia Jet tubers as well as Satsumo Imo and White Triumph cultivars proved to be homogeneous. In the case of infusions flooded with water at $80{ }^{\circ} \mathrm{C}$, the Cannanua, Carmen Rubin and Georgia Jet cultivars responded equally, and significantly higher antioxidant activity was found in the infusion from cultivars Satsumo Imo and White Triumph (Fig. 1). According to Różańska et al. (2014) affect changes in antioxidant potential during heat treatment by the loss of antioxidant vitamins, especially vitamin C, which is very sensitive to high temperatures. Dewanto et al. (2002) also obtained similar results, which due to the increase in infusion temperature found a reduction in the content of antioxidant compounds. Higher brewing temperature allowed for greater antioxidant activity of the leaves; the best effect of temperature difference was observed in the Georgia Jet cultivar, and the weakest in the Cananua cultivar. Similar differences in the antioxidant activity of other sweet potato cultivars were reported by Rumbaoa et al. (2009) and Hue et al. (2012). Končić et al. (2012) determined the antioxidant activity of water and ethanol extracts from sweet potato leaves, but also their effect on glucose-induced intracellular oxidative stress. Antioxidant activity was determined by DPPH radical scavenging activity, reducing potency, activity in $\beta$-caroten linoleic acid assay and superoxide dismutase-like activity. The ethanol extract has been found to be In addition to being richer in phenols and flavonoids than the aqueous extract, it also has excellent antioxidant activity in all tests. At a concentration of $10 \mu \mathrm{g} \mathrm{ml}^{-1}$, both extracts were able to significantly increase intracellular glutathione levels.

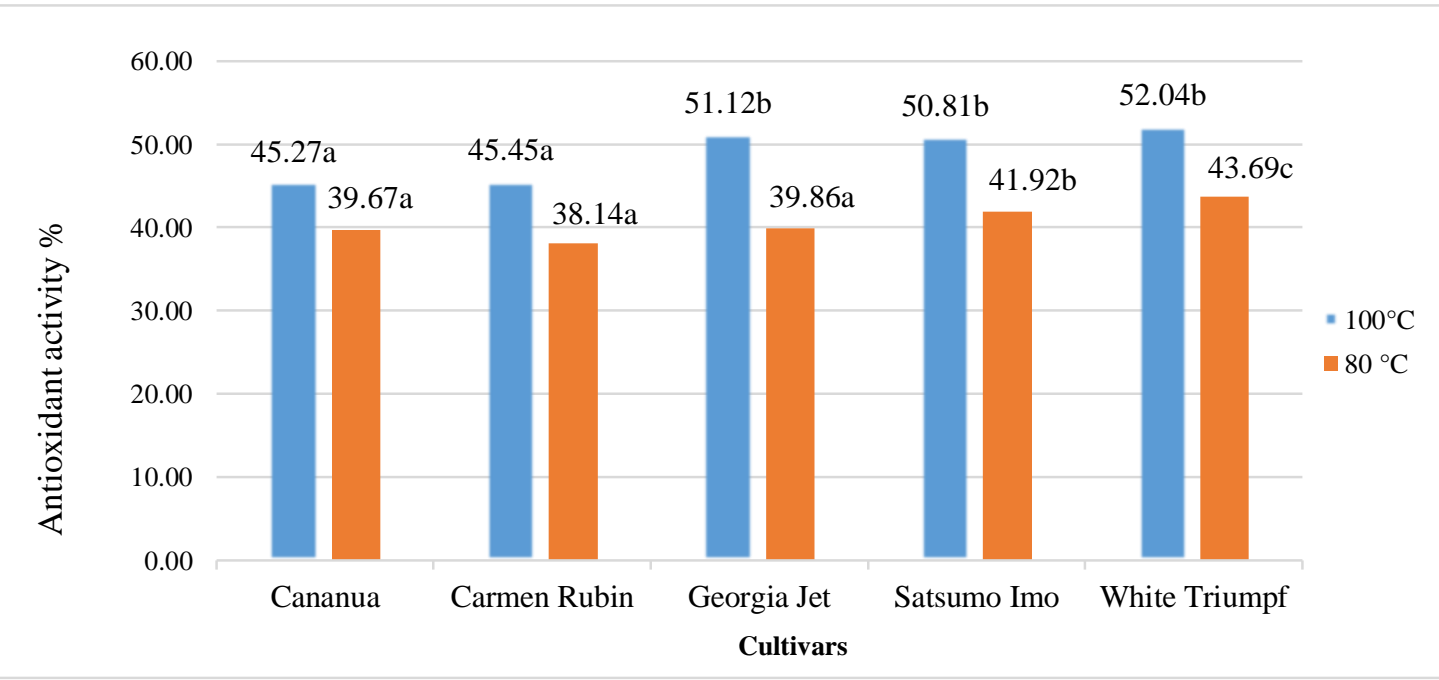

Figure 1. Influence of water temperature on antioxidant activity of infusions from cultivars of sweet potato leaves

Most of these methods are based on simple redox reactions between antioxidant and ROS (for example ABTS, DPPH, or FRAP tests). According to Koss-Mikołajczyk et al. (2017) however, chemical methods of assessing antioxidant activity are rarely biologically relevant. They do not mirror the real effect of antioxidants in living organisms, because they are used in non-physiological conditions of temperature and $\mathrm{pH}$; neither they take metabolism nor intracellular transport under consideration. The perfect model for assessment of antioxidant activity in living organisms would be human or animal model, but such determinations are very complicated and often ambiguous. The current best alternative to chemical and human tests is assays employing cell culture models being less expensive than human tests, yet still reflecting biological systems more convincingly than chemical assays. Cellular antioxidant assays are performed under physiological $\mathrm{pH}$ and temperature, but most importantly, they take metabolism and intracellular transport under consideration (Koss-Mikołajczyk et al. 2017).

\section{CONCLUSIONS}

1. Sweet potato leaf extracts have a great ability to capture radicals. The leaves of the White Triumph cultivar (from $7.80 \pm 2.19 \mathrm{mg}$ to $5.78 \pm 1.02 \mathrm{mg}$ gallic acid. $\mathrm{g}^{-1} \mathrm{DW}$ ), which had a higher TP content, had the highest radical capture activity. Increasing the brewing time resulted in a decrease in free radical scavenging activity. 
2. Antioxidant activity of infusions obtained from sweet potato leaves ranged from $32.6 \%$ to $58.0 \%$, depending on the cultivar and 32.8-44.93\%, depending on the length of time the infusion was prepared.

3. Infusions prepared at $100{ }^{\circ} \mathrm{C}$ had higher antioxidant activity than infusions prepared from water at $80{ }^{\circ} \mathrm{C}$.

4. Preparation time of infusions had a significant impact on antioxidant activity. The highest antioxidant activity was found after 6 minutes, and the lowest -3 minutes after infusion of dried sweet potato leaves.

5. Genetic features of sweet potatoes modified the value of the antioxidant potential of infusions obtained from leaves of this species. The highest antioxidant activity was characterized by infusions from leaves of the White Triumph and Georgia Jet cultivars, the lowest - from the leaves of the Cananua cultivar.

6. Due to the high content of polyphenols and due to the high antioxidant activity, sweet potato leaves can be an excellent raw material for food and pharmaceutical processing, for the production of teas and other anti-cancer products.

\section{REFERENCES}

1. Olovu A.O., Adeneye A.A., Olufunmilayo Adeyem O.O. 2011. Hypoglycemic effect of Ipomoea batatas aqueous leaf and stem extract in normal and streptozotocin-induced hyperglycemic rats. Journal of Natural Pharmaceuticals, Vol. 2, No. 2, pp. 56-60. https://doi.org/10.4103/2229-5119.83951.

2. $\quad$ Dewanto V., Wu X., Liu RH. 2002. Processed sweet corn has higher antioxidant activity. Journal of Agricultural and Food Chemistry, 17 (50), 4959 4964. https://doi.org/10.1021/if0255937

3. Dmowski M., Śmiechowska M., Sagan E. 2014. Influence of brewing time and the degree of grinding of black tea on the color of the infusion and its antioxidant properties. Food. Science. Technology. Quality, Vol. 5, No. 96, pp. 206-216. https://doi.org/10.15193/zntj/2014/96/206 (in polish)

4. Ghasemzadeh A, Jaafar HZE, Rahmat A 2010. Antioxidant activities, total phenolics and flavonoids content in two varieties of Malaysia young ginger (Zingiber officinale Roscoe). Molecules, Vol. 15, Iss. 6, pp. 4324-4333. https://doi.org/10.3390/molecules15064324

5. Ghasemzadeh A., Omidvar V., Jaafar H.Z.E. 2012. Polyphenolic content and their antioxidant activity in leaf extract of sweet potato (Ipomoea batatas). Journal of Medicinal Plants Research, Vol. 6, Iss. 15, pp. 2971-2976. https://doi.org/10.5897/JMPR11.1353

6. Hue S.M., Boyce A.N., Chandran S. 2012. Antioxidant activity, phenolic and flavonoid contents in the leaves of different varieties of sweet potato (Ipomoea batatas). Australian Journal of Crop Science, Vol. 6, Iss. 3, pp. 375-380.

7. Ishiguro K., Yoshimoto M. 2006. Content of an eye-protective nutrient lutein in sweet potato leaves. Acta Horticulture, Vo. 703, Iss. 32, pp. 253-256. https://doi.org/10.17660/ActaHortic.2006.703.32

8. Koss-Mikołajczyk I., Baranowska M., Namieśnik J., Bartoszek A. 2017. Determination of antioxidant activity of phytochemicals in cellular models by fluorescence/luminescence methods. Postepy Hig Med Dosw / Advances in Hygiene of Experimental Medicine (online) Vol. 71, pp. 1-16. https://doi.org/10.5604/01.3001.0010.3841

9. Karadag A., Ozcelik B., Saner S. 2009. Review of methods to determine antioxidant capacities. Food Anal. Methods, 2, 41 p.

10. Krochmal-Marczak B., Betlej I. 2014. Influence of sweet potato tuber extract (Ipomoea batatas [L.] LAM.) Grown in climate and soil conditions of Poland on the growth of mold fungi. Postępy Techniki Przetwórstwa Spożywczego/Technological Progress in food processing, Vol. 24/45 (2), pp. 92-94. (in polish)

11. Krochmal-Marczak B., Sawicka B., Michałek W. 2019. Photosynthetic Efficiency in Sweet Potato (Ipomoea batatas L. [Lam.]) under Different Nitrogen Fertilization Regimes. International Journal of Agriculture \& Biology, Vol. 22, Iss. 4, pp. 627-632. DOI: 10.17957/IJAB/15.1108.

12. Kubow S.,Iskandar M.M., Sabally K., Azadi B., Ekbatan S.S. Kumarathasan P., Das D.D., Prakash S., Burgos G., Felde T. 2016. Biotransformation of anthocyanins from two purple-fleshed sweet potato accessions in a dynamic gastrointestinal system. Food Chemistry, Vol. 192, pp. 171-177. https://doi.org/10.1016/j.foodchem.2015.06.105

13. Lobo V., Patil A., Phatak A., Chandra N. 2010. Free radicals, antioxidants and functional foods: Impact on human health. Pharmacognosy Reviews, Vol. 4, pp. 118-126. https://doi.org/10.4103/0973-7847.70902

14. Končić M.Z., Petlevski R., Kalođera Z. 2012. Antioxidant activity of Ipomoea Batatas L. Lam. A leaf grown in continental Croatia and its effect on glutathione levels in glucose-induced oxidative stress. International Journal of Food Properties, Vol. 16, Iss. 5, pp.12-23.

15. Kurata R, Adachi M., Yamakawa O., Yoshimoto M. 2007. Growth suppression of human cancer cells by polyphenolics from sweet potato (Ipomoea batatas L.) leaves. Journal of Agricultural and Food Chemistry, Vol. 55, Iss. 1, pp. 185-190. https://doi.org/10.1021/jf0620259

16. Rahman T., Hosen I., Islam M.M., Shekhar H.U. 2012. Oxidative stress and human health. Journal of Advances in Bioscience and Biotechnology, Vol. 3, pp. 997-1019. https://doi.org/10.4236/abb.2012.327123

17. Ray P.D, Huang B.W., Tsuji Y. 2012. Reactive oxygen species (ROS) homeostasis and redox regulation in cellular signaling. Cellular Signalling, Vol. 24, Iss. 5, pp. 981-990. https://doi.org/10.1016/j.cellsig.2012.01.008

18. Różańska D., Regulska-Ilow B., Ilow R. 2014. The impact of selected culinary processes on the antioxidant potential and content of polyphenols in food. Problems of Hygiene and Epidemiology, Vol. 95, Iss. 2, pp. 215-222. (in polish)

19. Rumbaoa RG., Cornago DF., Geronimo IM. 2009. Phenolic content and antioxidant capacity of Philippine sweet potato (Ipomoea batatas) varieties. Food Chemistry, Vol. 113, Iss. 4, pp. 1133-1138. https://doi.org/10.1016/j.foodchem.2008.08.088

20. Sawicka B., Pszczółkowski P., Mikos-Bielak M. 2000. Biological value of tubers Ipomoea batatas [L.] Lam. in the Lublin region. Yearbook of the Agricultural University of Poznań Horticulture, Vol. 323 (31/1), pp. 453-457. (in polish)

21. Sawicka B., Pszczółkowski P., Krochmal-Marczak B. 2004. Quality of tubers Ipomoea batatas [L.] Lam. grown under nitrogen fertilization. Annales UMCS Sectio E - Agricultura, Vol. 59, Iss. 3, pp. 1223-1232. (in polish)

22. Sawicka B., Michałek W., Pszczółkowski P., Danilčenko H. 2018. Variation in productivity of sweet potato (Ipomoea batatas L. [Lam.]) under different conditions of nitrogen fertilization. Zemdirbyste-Agriculture, Vol. 105, No. 2, pp. 149-158. https://doi.org/10.13080/z-a.2018.105.019

23. Schieber M., Navdeep S. Chandel, 2014. ROS Function in Redox Signaling and Oxidative Stress. Current Biology, Vol. 24 , No. 10, R 453-462. https://doi.org/10.1016/j.cub.2014.03.034

24. Sies H. 2015. Oxidative stress: a concept in redox biology and medicine. Redox Biology, Vol.4, pp. 180-183. https://doi.org/10.1016/j.redox.2015.01.002 
25. Sun H., Zhang P., Zhu Y., Lou Q., He S. 2018. Antioxidant and prebiotic activity of five anthocyanins based on peonidine extracted from purple sweet potatoes (Ipomoea batatas (L.) Lam.). Scientific Reports, Vol. 8, Iss. 1(5018), pp. 1-12 . https://doi.org/10.1038/s41598-018-23397-0

26. Stanisz A. 2007. An affordable statistics course using Statistica Pl on examples from medicine. T. 3. Multidimensional analyzes. StatSoft. (in polish)

27. Towne V., Will M., Oswald B., Zhao Q. 2004. Complexities in horseradish peroxidase-catalyzed oxidation of dihydroxyphenoxazine derivatives: appropriate ranges for $\mathrm{pH}$ values and hydrogen peroxide concentrations in quantitative analysis. Analytical Biochemistry, Vol. 334, pp. 290-296. https://doi.org/10.1016/j.ab.2004.07.037

28. Wang JTL, Shan H, Shasha D., Piel W.H. 2005. Fast Structural Search in Phylogenetic Databases. Evolutionary Bioinformatics, Vol. 1, pp. 37-46, https://doi.org/10.1177/117693430500100009

29. Ye Z.W., Zhang J., Townsend D.M., Tew K.D. 2015. Oxidative stress, redox regulation and diseases of cellular differentiation. Biochim Biophys Acta, Vol. 1850, Iss. 8, pp. 1607-1621. https://doi.org/10.1016/j.bbagen.2014.11.010

30. Yen G.H., Chen H.Y., 1995. Antioxidant Activity of Various Tea Extracts in Relation to Their Antimut agenicity. Journal of Agricultural and Food Chemistry, Vol. 43, pp. 27-32. https://doi.org/10.1021/jf00049a007

31. Zuo L., Zhou T., Pannell B.K., Ziegler A.C., Best T.M. 2015. Biological and physiological role of reactive oxygen species - the good, the bad and the ugly. Acta Physiologica, Vol. 214, pp. 329-348. https://doi.org/10.1111/apha.12515

32. Zych J., Krzepiłko A. 2010. Pomiar całkowitej zdolności antyoksydacyjnej wybranych antyoksydantów i naparów metodą redukcji rodnika DPPH, Metrologia; Vol. 15, No. 1, pp. 51-54. 